Article

\title{
Kaolinite-Magnesite or Kaolinite-Talc-Based Ceramics. Part II: Microstructure and the Final Properties Related Sintered Tapes
}

\author{
Aghiles Hammas ${ }^{1}\left(\mathbb{D}\right.$, Gisèle Lecomte-Nana ${ }^{2, *(\mathbb{D})}$, Imane Daou ${ }^{2}$, Nicolas Tessier-Doyen ${ }^{2}$, \\ Claire Peyratout ${ }^{2}$ and Fatima Zibouche ${ }^{1}$ \\ 1 Laboratoire de Traitement et Mise en Forme des Polymères Fibreux, Faculté des Sciences, \\ Université M’Hamed Bougara Boumerdes, Boumerdes 35000, Algeria; \\ aghiles.hammas@univ-boumerdes.dz (A.H.); zibouchefatima@yahoo.fr (F.Z.) \\ 2 Institut de Recherche sur les Céramiques (IRCER, UMRCNRS 7315), ENSIL-ENSCI, Université de Limoges, \\ CEC, 12 rue Atlantis, CEDEX, 87068 Limoges, France; imane.daou@unilim.fr (I.D.); \\ nicolas.tessier-doyen@unilim.fr (N.T.-D.); claire.peyratout@unilim.fr (C.P.) \\ * Correspondence: gisele.lecomte@unilim.fr
}

Received: 28 October 2020; Accepted: 27 November 2020; Published: 1 December 2020

\begin{abstract}
In recent decades, talc and kaolinite have been widely used as raw materials for the ceramic industry. In this study, the final characteristics of kaolinitic clay mixed with 6 mass $\%$ of magnesite obtained in our previous work were compared with those obtained with mixtures of kaolin (kaolin $\mathrm{BIP}$ ) and talc (as the source of magnesium oxide). However, different amounts of talc in the kaolin powder were studied, namely 10, 30, and 50 mass $\%$ of added talc (with respect to kaolin + talc). The tape casting process was used during this work in order to manufacture the green tapes in an aqueous system with 0.2 mass $\%$ of dispersant. Subsequently, the green tapes were heated to 1000 and $1100{ }^{\circ} \mathrm{C}$ with a dwelling time of $12 \mathrm{~min}$. The green and sintering tapes were characterized using the following techniques: DTA/TG, X-ray diffraction, porosity, and flexural strength analyses. The results obtained from our previous work indicate that the specimen with 6 mass $\%$ of $\mathrm{MgCO}_{3}$ sintered at $1200{ }^{\circ} \mathrm{C}$ for $3 \mathrm{~h}$ exhibited the best performances, with high flexural strength and weak porosity value - $117 \mathrm{MPa}$ and $27 \%$-respectively. As results from this study, the optimal mechanical and thermal properties of sintering tapes were obtained for the specimen with 10 mass $\%$ of added talc sintered at $1100{ }^{\circ} \mathrm{C}$. Indeed, this specimen exhibited $50 \mathrm{MPa}$ and $43 \%$ of stress to rupture and apparent porosity, respectively.
\end{abstract}

Keywords: kaolinite; talc; magnesite; tape casting; biaxial flexural strength

\section{Introduction}

Many traditional and advanced ceramic materials are made from clay (or clay mixed with other materials) [1-4]. Indeed, the mixture of two or more clays of different composition and texture to form a paste is performed to improve the workability and firing behavior in comparison to the behavior of each single clay. Additionally, the blending of sediments with different proportions of clay and non-clay particles and/or different clay minerals is commonly used to enhance the final properties of some ceramics [5,6]. However, kaolinite and talc are both phyllosilicate minerals which present considerable interest to produce several types of ceramic materials (traditional and advances ceramics) for having certain valuable properties [7-11]. The addition of talc has positive effects on ceramic-for example, it increases the mechanical and optical properties of the ceramic material and glazes [12-14].

Kaolinite has a 1:1 sheet structure with chemical formulae $\mathrm{Al}_{2} \mathrm{Si}_{2} \mathrm{O}_{5}(\mathrm{OH})_{4}\left(39.8\right.$ mass $\% \mathrm{Al}_{2} \mathrm{O}_{3}$, $46.38 \mathrm{mass} \% \mathrm{SiO}_{2}$, and 13.9 mass $\% \mathrm{H}_{2} \mathrm{O}$ ). It is a layered clay mineral consisting of the pilling up of two 
sheets—one tetrahedral sheet of silica $\left(\mathrm{SiO}_{4}\right)$ joined to one octahedral sheet of alumina $\left(\mathrm{AlO}_{6}\right)$ [15-18]. Indeed, the morphology of kaolinite mineral is plate-like. Its crystal system is triclinic with a C1-based space group. According to literature [19], the unit cell structure of kaolinite is illustrated in Figure 1.

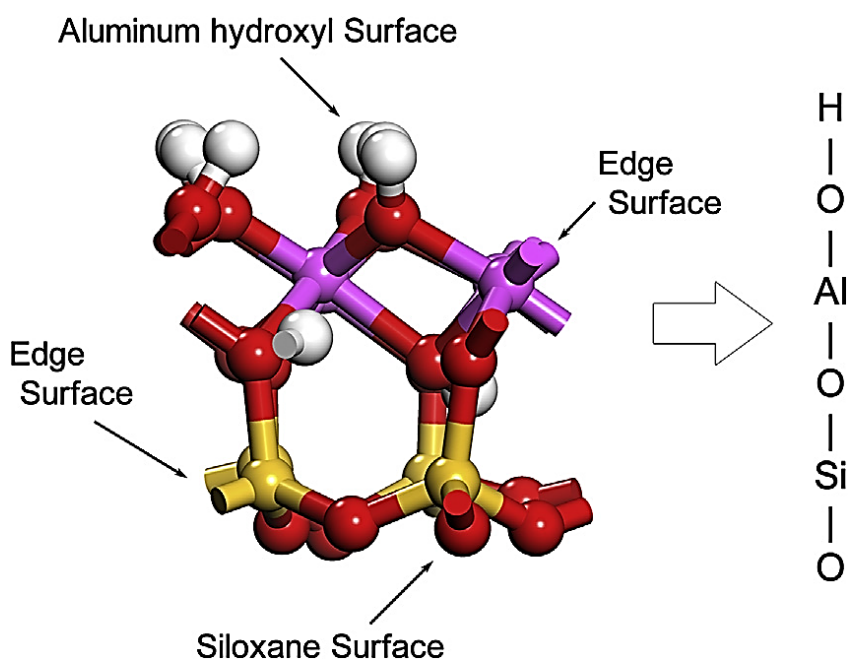

Figure 1. Structure of kaolinite primitive cell (white, hydrogen; red oxygen; pink, aluminum; yellow, silicon) [19].

On the other hand, talc is a magnesium hydrosilicate with the theoretical formula $3 \mathrm{MgO} \cdot 4 \mathrm{SiO}_{2} \cdot \mathrm{H}_{2} \mathrm{O}$, corresponding to 63.35 mass $\% \mathrm{SiO}_{2}, 31.90$ mass $\% \mathrm{MgO}$, and 4.75 mass $\%$ of chemically bound water (hydroxide) [20]. In contrast, other minerals can be associated with talc, such as, chlorites, mica, actinolite, feldspars, rutile, pyrrhotite, carbonates, pyrite, magnetite, and hematite [12]. The crystalline structure of talc has a 2:1 or TOT layer type with one octahedral $(\mathrm{O})$ magnesium layer sandwiched between two tetrahedral silica layers (Figure 2) [21].

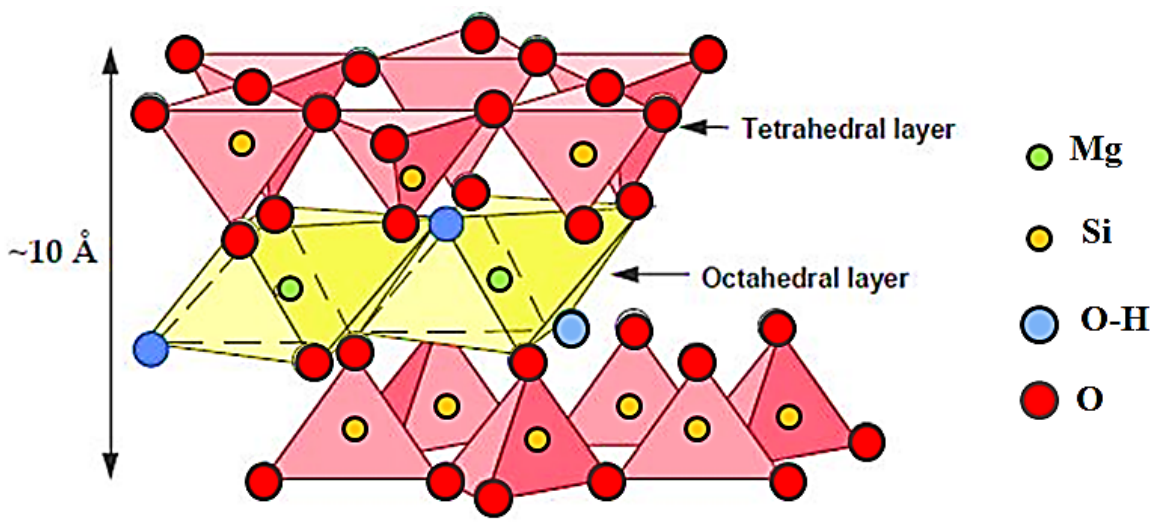

Figure 2. Schematic representation of the talc structures.

In our previous work [1,17], the effect of magnesite amount on the different properties of kaolinitic clay ceramics was studied. However, in this study, we aimed to compare the final characteristics of the kaolinitic clay from Algeria (KT2) mixed with 6 mass \% of magnesite, with those resulting from the use of a commercial kaolin (kaolin BIP) mixed with talc (as the source of magnesium oxide). Several mass contents of talc in the kaolin powder were investigated-10, 20,30, 40, and 50 mass \% of added talc. In a former paper, we suggested a firing temperature of up to $1200{ }^{\circ} \mathrm{C}$, but the use of talc (melting of samples) did not allow performing heat treatments above $1100^{\circ} \mathrm{C}$. The structural changes $(\mathrm{XRD}, \mathrm{SEM})$, the mechanical, and thermal properties of the manufactured samples using tape casting were analyzed before and after sintering at 1000 and $1100{ }^{\circ} \mathrm{C}$. 


\section{Materials and Methods}

\subsection{Raw Materials}

In the present study, two kaolins were used: kaolinitic clay KT2 from Algeria (Tamazert, El Milia, Jijel, Algeria) and a commercial kaolin noted kaolin BIP the kaolin (Kaolin de Beauvoir, Imerys Limoges, France). The magnesite and the talc were provided by $\mathrm{x}$ and $\mathrm{y}$, respectively. The chemical compositions of these raw materials are shown in Table 1. In this study, the kaolin KT2 was mixed with magnesite (KxMy), and kaolin BIP was mixed with talc (KxTy); in addition, T100 is $100 \%$ of talc.

Table 1. Chemical composition (XRF analyses) and other characteristic physical properties of the starting powders. LOI, loss on ignition at $1050{ }^{\circ} \mathrm{C}$.

\begin{tabular}{|c|c|c|c|c|c|c|c|c|c|c|c|c|}
\hline \multirow{2}{*}{$\begin{array}{c}\text { Raw } \\
\text { Material }\end{array}$} & \multirow{2}{*}{$\begin{array}{c}\text { SSA (BET) } \\
( \pm 0.1 \\
\left.\mathrm{m}^{2} \cdot \mathrm{g}^{-1}\right)\end{array}$} & \multirow{2}{*}{$\begin{array}{l}\text { Density } \\
\left(\mathrm{g} \cdot \mathrm{cm}^{-3}\right)\end{array}$} & \multicolumn{10}{|c|}{ Chemical Composition (mass \%) } \\
\hline & & & $\mathrm{SiO}_{2}$ & $\mathrm{Al}_{2} \mathrm{O}_{3}$ & $\mathrm{MgO}$ & $\mathrm{Fe}_{2} \mathrm{O}_{3}$ & $\mathrm{TiO}_{2}$ & $\mathrm{Li}_{2} \mathrm{O}$ & $\mathrm{CaO}$ & $\mathrm{Na}_{2} \mathrm{O}$ & $\mathrm{K}_{2} \mathrm{O}$ & LOI \\
\hline $\begin{array}{l}\text { Kaolinitic } \\
\text { clay KT2 }\end{array}$ & 25.0 & 2.6 & 47.8 & 32.9 & 0.6 & 3.5 & 0.5 & - & 0.1 & 0.1 & 2.9 & 11.5 \\
\hline $\begin{array}{c}\text { Kaolin } \\
\text { BIP }\end{array}$ & 11.7 & 2.6 & 48.1 & 39.9 & 0.17 & 0.26 & $<0.25$ & 0.27 & $<0.2$ & $<0.2$ & 1.9 & 10 \\
\hline Talc & 11.0 & 2.7 & 63 & 0.2 & 30.5 & 1.4 & $<0.1$ & - & 0.25 & 0.03 & 0.01 & 4.7 \\
\hline Magnesite & 11.7 & 2.9 & 3.2 & 0.1 & 42.7 & 0.4 & - & - & 3.2 & - & - & 50.4 \\
\hline K94M6 & & & 45.0 & 30.9 & 3.1 & 3.3 & 0.4 & - & 0.3 & 0.1 & 2.7 & 13.8 \\
\hline K90T10 & & & 49.6 & 35.9 & 3.2 & 0.4 & $<0.23$ & 0.24 & 0.2 & 0.18 & 1.7 & 9.5 \\
\hline K80T20 & & & 51.1 & 31.9 & 6.2 & 0.5 & $<0.2$ & 0.22 & 0.2 & 0.16 & 1.5 & 8.9 \\
\hline К70Т30 & & & 52.6 & 28 & 9.3 & 0.6 & $<0.17$ & 0.2 & 0.2 & 0.14 & 1.3 & 8.4 \\
\hline K60T40 & & & 54.1 & 24 & 12.3 & 0.7 & $<0.15$ & 0.16 & 0.2 & 0.12 & 1.14 & 7.9 \\
\hline K50T50 & & & 55.6 & 20.1 & 15.3 & 0.8 & 0.18 & 0.13 & 0.2 & 0.1 & 0.95 & 7.4 \\
\hline
\end{tabular}

Different organics additives were added to the mixture slurries, such as dispersant, binder, and plasticizer, which are dolaflux, polyvinyl alcohol (PVA 2200, VWR Prolabo, Geldenaaksebaan, Belgium), and polyethylene glycol (PEG 300, VWR, Prolabo, Germany), respectively.

\subsection{Dispersions Preparation}

Before dispersing of mixture slurries (kaolin/talc), $0.1 \mathrm{~g} \cdot \mathrm{mL}^{-1}$ dispersant solutions were prepared via dissolving of Dolaflux in a $3 \mathrm{M} \mathrm{NaOH}$ solution. The aqueous suspensions with 62.5 mass $\%$ of solid loading were dispersed with $0.1,0.2$, and 0.3 mass $\%$ of dispersant (respect to the clay content). The kaolinitic clay KT2 with and without 6 mass \% of magnesite was consider in this paper. Nevertheless, different talc amounts were added to the kaolin suspension, namely, 10, 20, 30, 40, and 50 mass $\%$. At the same time, all suspensions were mixed using a roll mixer for $24 \mathrm{~h}$ at room temperature in order to promote interactions between the clay particles and additives while removing residual air bubbles. The dispersion and formulation optimization have been already described in our former paper (part I.) [17].

After the dispersion step for the kaolin BIP and talc mixtures, the organic additives such as binder and plasticizer were added to these suspensions, polyvinyl alcohol (PVA 2200) and polyethylene glycol (PEG 300), respectively, which was ground in a planetary mill for $16 \mathrm{~h}$ at $100 \mathrm{rpm}$. The relative mass ratio between binder and plasticizer was equal to 1 in this study. However, a solution of $0.16 \mathrm{~g} \cdot \mathrm{mL}^{-1}$ binder was prepared by incorporating PVA slowly in deionized water, which was previously heated at $80{ }^{\circ} \mathrm{C}$. During the addition of PVA, the solution was continuously stirred in order to avoid the formation of a gel. Prior to the tape casting, the slurries were de-aired on rollers for $22 \mathrm{~h}$ and sieved at $100 \mu \mathrm{m}$ to ensure the elimination of the non-dissolved binder or impurities. 


\subsection{Preparation of Green and Sintered Bodies}

Different slurries were cast under $10 \mathrm{~mm} / \mathrm{s}$ of speed with a gap of $1 \mathrm{~mm}$ (thickness) between the blade and the casting support. After drying, the samples were cut in pellet. Once the green tapes were dried at room temperature $(12 \mathrm{~h}$ ), specimens of $30 \mathrm{~mm}$ diameter (disks) were collected using a circular punch. These samples were sintered in an electric furnace at a heating rate of $5^{\circ} \mathrm{C} / \mathrm{min}$ up to $1000{ }^{\circ} \mathrm{C}$, and $1100{ }^{\circ} \mathrm{C}$, dwelling time of $12 \mathrm{~min}$ at the maximum temperature. A cooling rate of $5{ }^{\circ} \mathrm{C} / \mathrm{min}$ was used to decrease to room temperature. Figure 3 illustrated the shape and color of kaolin-talc-based tapes after sintering at 1000 and $1100^{\circ} \mathrm{C}$.

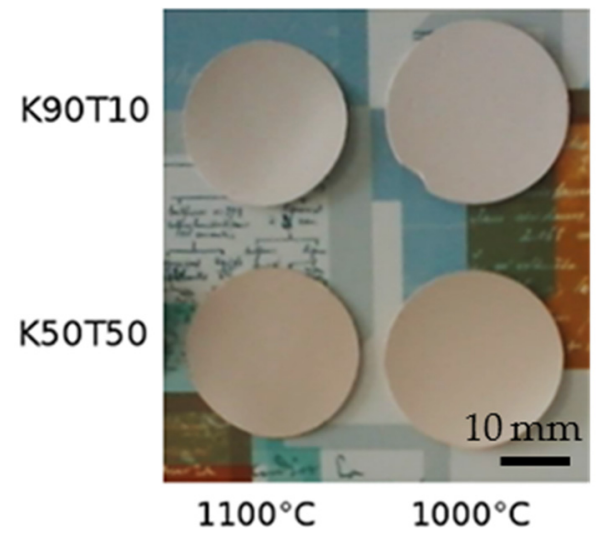

Figure 3. Samples after heat treatments at 1000 and $1100{ }^{\circ} \mathrm{C}$ (soaking time of $12 \mathrm{~min}$ ).

\subsection{Characterization Techniques}

\subsubsection{Thermal Analysis}

Differential thermal and gravimetric analyses (DTA/DTG) were measured using SETSYS 2400 DTA-TGA equipment from SETARAM (Caluire, France). The analysis was carried out under the temperature range $25-1300{ }^{\circ} \mathrm{C}$ at a heating rate of $5{ }^{\circ} \mathrm{C} / \mathrm{min}$ using dried-air atmosphere (for all experiments, Pt crucibles were used). The thermal behavior helped to determine the most appropriate thermal cycle during sintering in order to avoid crack formation within sintered products.

\subsubsection{Apparent Porosity}

During this study, the apparent porosity of green and sintered specimens (ISO 11272:2017) was calculated using equation (Equation (1)). However, the bulk density $\left(\rho_{\text {bulk }}\right)$ was determined from weight and dimensional measurements; apparent density ( $\left.\rho_{\text {apparent }}\right)$ was estimated using a Micromeritics AccuPyc II 1340 helium-pycnometer (Norccross, GA, USA).

$$
P=\left(1-\frac{\rho_{\text {bulk }}}{\rho_{\text {apparent }}}\right)
$$

\subsubsection{X-Ray Diffraction}

X-ray diffraction measurement of the samples was performed using a Bruker D5000 X-ray powder diffractometer (Bruker, Karlsruhe, Germany) equipped with a crystal monochromator ( $\mathrm{Cu}-\mathrm{K} \alpha$ radiation equal to $1.5406 \AA$ ) at room temperature. The measurements were achieved at $40 \mathrm{kV}$ and $30 \mathrm{~mA}$ in a $2 \theta$ range from $2^{\circ}$ to $70^{\circ}$, with a $2 \theta$ scanning rate of $0.5^{\circ} / \mathrm{min}$ and a step of $0.02^{\circ}$.

\subsubsection{Scanning Electron Microscopy}

In order to observe the microstructure of the samples, scanning electron microscope (SEM) observations (Stereosacan Cambridge S260 SEM microscope, Oxford Instruments, Abingdon, UK), 
were performed on the bottom and upper faces as well as on the sides of tapes. To prepare samples, the upper and bottom faces of specimens were set on carbon adhesive patches to stick to the sample holder. Fractures of tapes were set vertically on carbon paste to observe slices. Silver lacquer was evenly applied on sample surfaces. In all cases, a $15 \mathrm{~mm}$ gold layer was deposited in order to improve the electrical conduction at the surface of samples (to improve the quality of the images).

\subsubsection{Biaxial Flexural Strength}

The mechanical properties of each green and sintered tape with different talc amounts were assessed by the measurement of the biaxial flexural strength through universal machine Lloyd Easy Test EZ 20 (Largo, FL, USA) equipped with a piston-ring configuration. The crosshead velocity and the preload were fixed at $1 \mathrm{~mm} \cdot \mathrm{min}^{-1}, 0.2 \mathrm{~N}$, respectively. A high sensitivity sensor $(100 \mathrm{~N})$ was chosen because load submitted to specimens has to represent at least $1 \%$ of the maximum range. Samples used for biaxial bending tests were shaped as $30 \mathrm{~mm}$ in diameter disks.

For the piston on the three ball test, the modified Kirstein and Woolley's [22] equation for the maximum biaxial flexure strength (in $\mathrm{MPa}$ ) was:

$$
\sigma_{R}=\frac{3 P_{R}(1+v)}{4 \pi e^{2}}\left(1+2 \times \ln \frac{A}{B}+\left(\frac{1-v}{1+v}\right) \times\left(1-\frac{B^{2}}{2 A^{2}}\right) \times \frac{A^{2}}{C^{2}}\right)
$$

In this formula, $P_{R}$ is the ultimate sustained load, $A$ is the diameter of the ring equal to $28 \mathrm{~mm}$ of the support ring, $B$ is diameter of the upper piston equal to $5 \mathrm{~mm}, C$ is the specimen diameter $(\mathrm{mm})$, $e$ is the specimen thickness $(\mathrm{mm})$, and $v$ is Poisson's ratio (0.25). For all tested specimens, diameter (C) was voluntarily chosen as $30 \mathrm{~mm}$. For each set of specimens, 5 values of stress to rupture were measured, and the results presented are the mean values of each series of 5 measurements.

\section{Results and Discussion}

\subsection{XRD, Thermal Behavior and Microstructure of Green and Sintered Specimens}

In order to the determine DTA and TG curves for the different Mg-enriched kaolin samples, the final properties of samples after sintering at 1000 and $1100{ }^{\circ} \mathrm{C}$ were characterized. The typical behavior of the prepared tapes are presented on Figure 4. Indeed, four main transformations were observed in all our samples, namely:

- $\quad$ The dehydration of the green tapes in the region between 70 and $120^{\circ} \mathrm{C}$ (endothermic peak);

- The burning of organics used as binders and plasticizer in the range 150 to $400{ }^{\circ} \mathrm{C}$ (consecutive exothermic peaks associated with significant mass loss);

- The dehydroxylation of kaolinite between 400 and $650{ }^{\circ} \mathrm{C}$, characterized by an endothermic peak which appeared proportional to the kaolin content in the mixture (also the related mass loss);

- The dehydroxylation of talc in the range 850 to $1000{ }^{\circ} \mathrm{C}$, characterized by an endothermic peak (proportional to the talc content as the mass loss) very close to the exothermic peak associated to the structural reorganization of the metakaolinite.

Considering these thermal analyses results, it appeared that above $1100{ }^{\circ} \mathrm{C}$, an important melting occurred within our kaolin-talc tapes; thus, it was decided to conduct the heat treatments at 1000 and $1100{ }^{\circ} \mathrm{C}$ in line with the characterization of apparent porosity and flexural strength.

First, the crystalline phase of green and sintered tapes were analyzed using XRD measurements. The obtained XRD patterns are presented on Figures 5 and 6. 

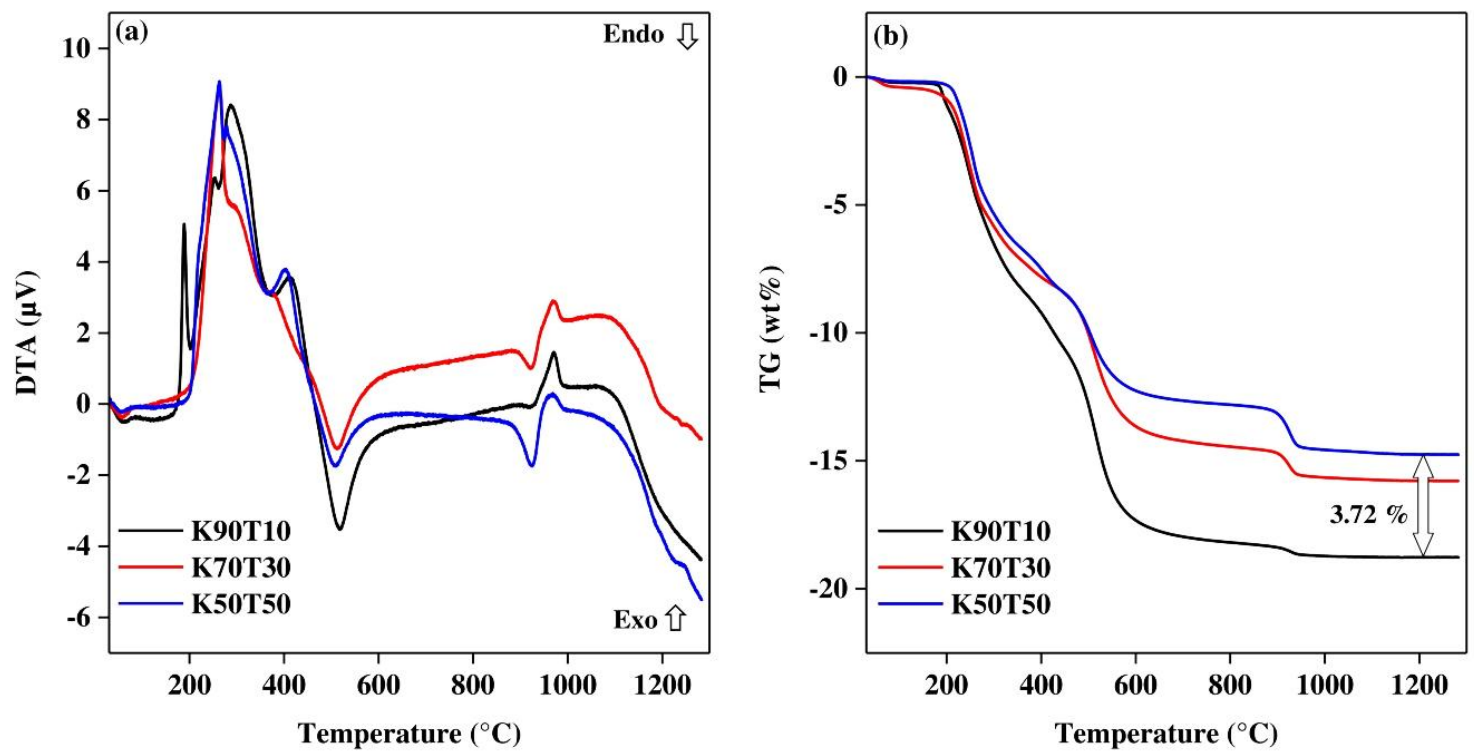

Figure 4. DTA (a) and TG (b) curves of three kaolin-talc tapes (under air up to $1200{ }^{\circ} \mathrm{C}$ ), $\mathrm{K} 50 \mathrm{~T} 50$, K70T30, and K90T10.

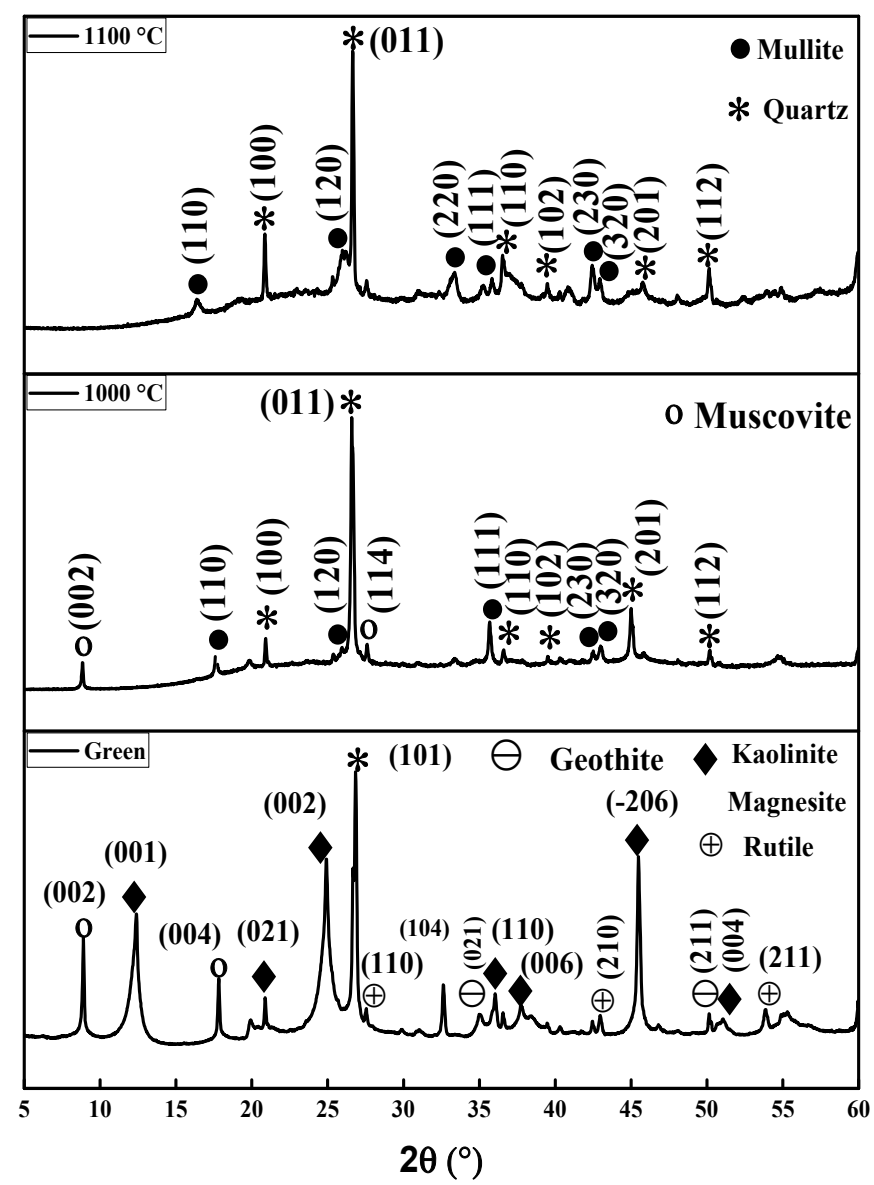

Figure 5. XRD patterns of K94M6 (green tapes and tapes sintered at 1000 and $1100{ }^{\circ} \mathrm{C}$ ). 


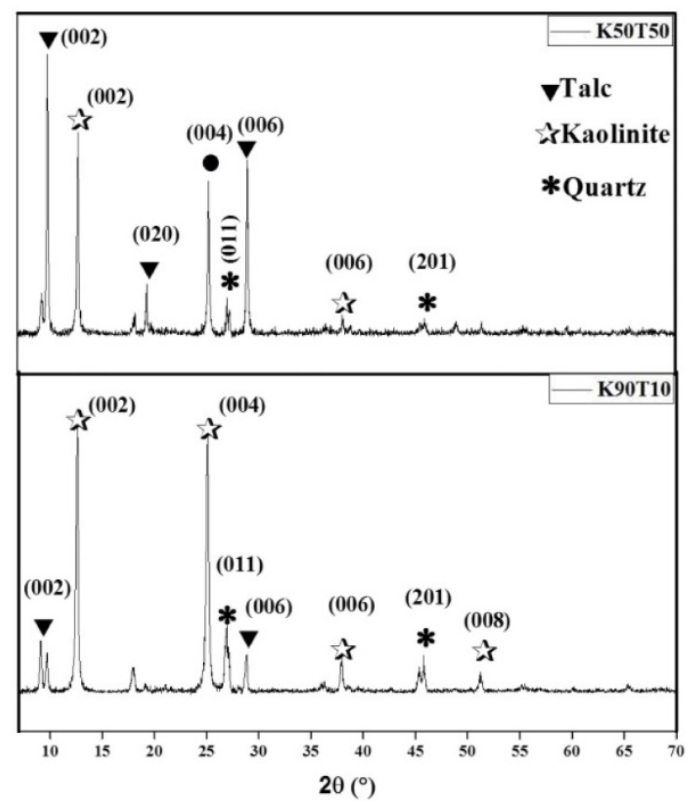

(a)

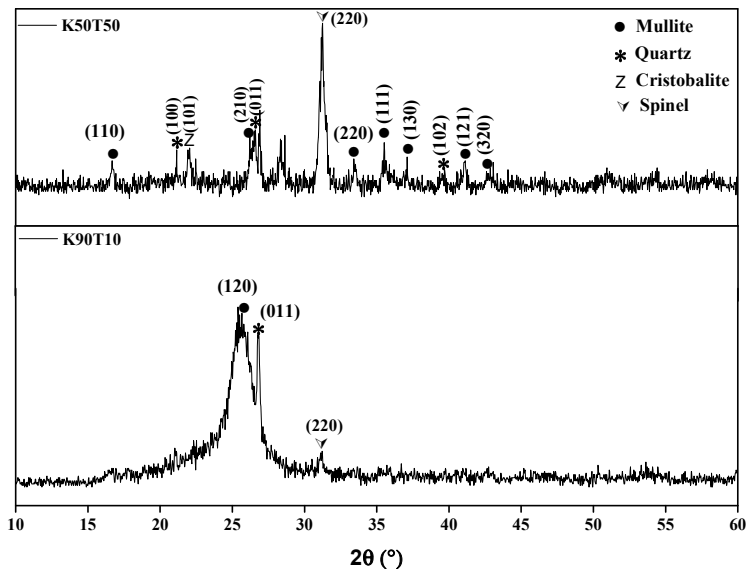

(b)

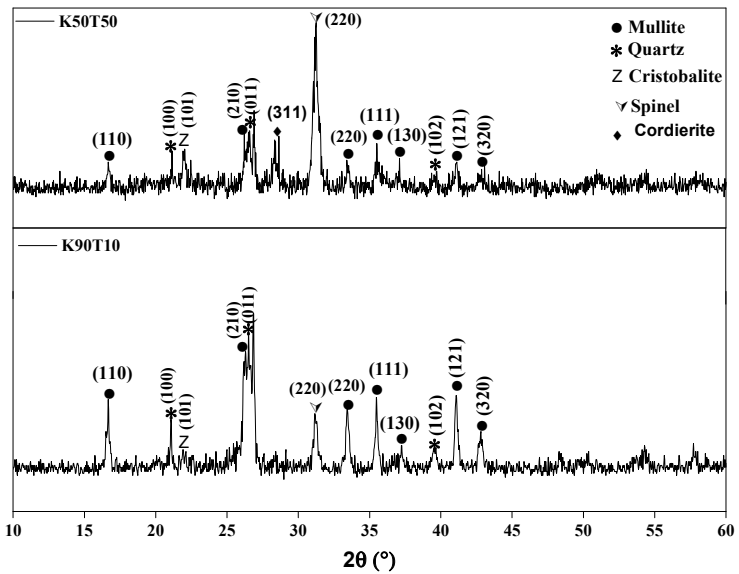

(c)

Figure 6. XRD patterns of K90T10 and K50T50 tapes: (a) green samples, (b) samples sintered at $1000{ }^{\circ} \mathrm{C}$, and (c) samples sintered at $1100{ }^{\circ} \mathrm{C}$.

For the samples K94M6, the main crystallized phases appeared to be few quartz (JCPDS 01-070-7344) and mullite (JCPDS 00-015-0776). Cordierite phase (JCPDS 00-012-0303) seemed to be present through the very small diffraction peak located at $15^{\circ}$ and $29.7^{\circ}(2 \theta)$. The reaction sequence could be summarized regarding the Equations (3)-(7), with Equations (3) and (4) for the formation of primary and secondary mullite, and Equations (5) and (7) for the crystallization of cordierite [23-25]. Equation (5) characterized the decarbonation of magnesite prior to its reaction with alumina to form a spinel phase. Note that the competition between the crystallization of mullite and the formation of cordierite tended to be profitable to mullite until temperature close to $1200{ }^{\circ} \mathrm{C}$.

$$
\begin{gathered}
2\left(\mathrm{Al}_{2} \mathrm{Si}_{2} \mathrm{O}_{5}\right) \rightarrow \\
3\left(\mathrm{Al}_{2} \mathrm{Si}_{2} \mathrm{O}_{5}\right) \rightarrow \\
2\left(3 \mathrm{Al}_{2} \mathrm{O}_{3} \cdot 3 \mathrm{O}_{3} \cdot 2 \mathrm{SiO}_{2}\right)+5 \mathrm{SiO}_{2} \text { (amorphous) } \\
\quad \mathrm{MgCO}_{3} \rightarrow \mathrm{MgO}+\mathrm{CO}_{2} \\
2\left(\mathrm{MgO} \cdot \mathrm{Al}_{2} \mathrm{O}_{3}\right)+5\left(\mathrm{SiO}_{2}\right) \rightarrow\left(2 \mathrm{MgO} \cdot 2 \mathrm{Al}_{2} \mathrm{O}_{3} \cdot 5 \mathrm{SiO}_{2}\right)
\end{gathered}
$$




$$
5\left(3 \mathrm{Al}_{2} \mathrm{O}_{3} \cdot 2 \mathrm{SiO}_{2}\right)+15 \mathrm{MgO} \rightarrow 2\left(2 \mathrm{MgO} \cdot 2 \mathrm{Al}_{2} \mathrm{O}_{3} \cdot \mathrm{SiO}_{2}\right)+11\left(\mathrm{MgO} \cdot \mathrm{Al}_{2} \mathrm{O}_{3}\right)
$$

In the case of kaolin-talc mixtures, we detected the presence of spinel and cristobalite (due to the structural reorganization of metakaolinite) after sintering at $1000^{\circ} \mathrm{C}$. In addition, the sintering of these samples at $1100{ }^{\circ} \mathrm{C}$ tended to enhance the crystallization of mullite (JCPDS 00-015-0776) and the formation of cordierite (JCPDS 00-012-0303) as expected. The observation of their microstructure by SEM (Figure 7) showed a significant change in the shape of the clay platelets, which appeared with rounded corners due the formation of transitory liquid phases in agreement with the ternary phase diagram $\mathrm{SiO}_{2}-\mathrm{Al}_{2} \mathrm{O}_{3}-\mathrm{MgO}$.

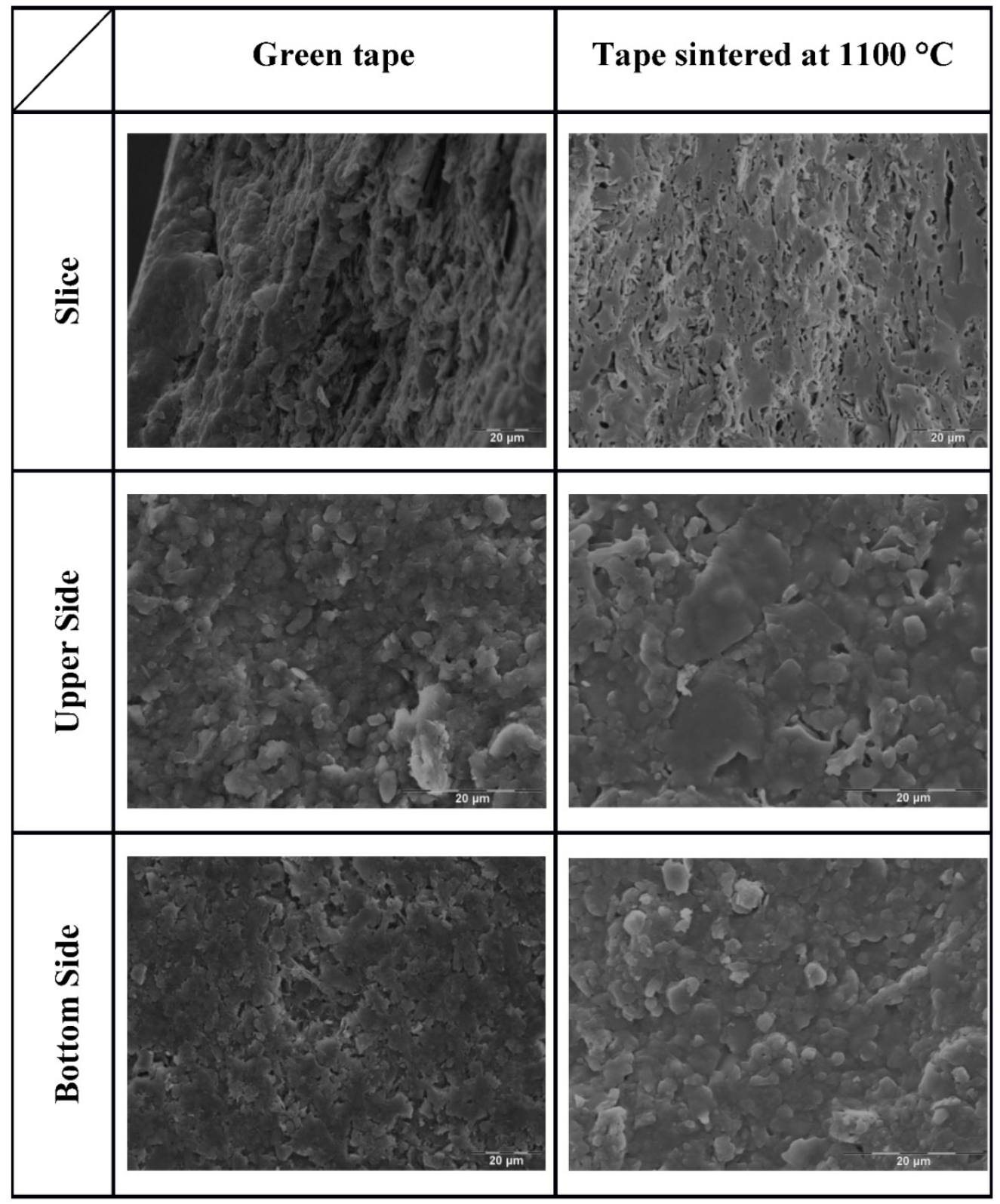

Figure 7. Typical SEM images of the kaolin-talc tapes K90T10 before and after sintering at $1100{ }^{\circ} \mathrm{C}$.

\subsection{Mechanical Properties and Porosity}

After sintering of the various specimens, the obtained biaxial flexural strength and apparent porosity are presented in Figures 8 and 9. In the green tapes, the addition of talc to kaolin tended to decrease the stress to rupture, while the apparent porosity was close to $40 \%$ in all cases (see Figure $9 \mathrm{~b}$ ). 
A similar trend was observed with the sample KT2M6 compared to KT2. This behavior seemed to be related to the higher plasticity of the kaolin used in this study compared to the talc material or to the magnesite. However, according to our previous study [1], it was indicated that the mechanical properties of K94M6 tapes were strongly affected by their microstructure, and as a result, biaxial flexural strength increased when porosity decreased [26]. Consequently, it appears in Figure 8 that the stress to rupture values decreased while sintering at 1000 or $1100{ }^{\circ} \mathrm{C}$. Moreover, the decarbonation of magnesite contributed to increasing the apparent porosity of K94M6 samples after sintering up to $1100{ }^{\circ} \mathrm{C}$, thus to observed decrease the biaxial flexural strength down to $10 \mathrm{MPa}$.

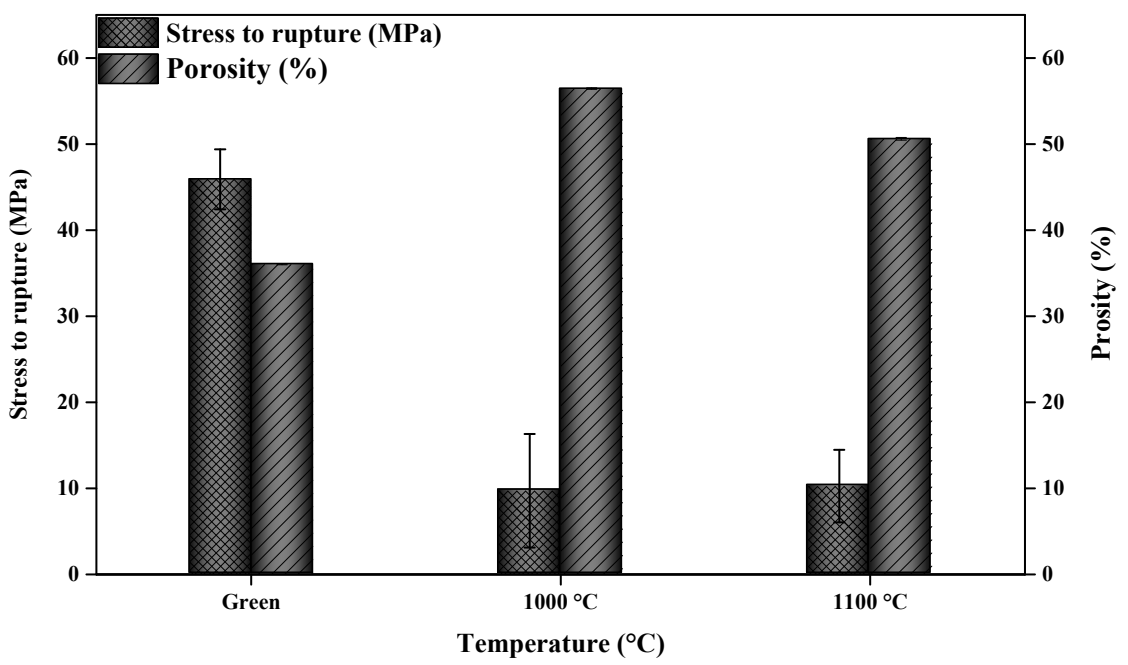

Figure 8. Mechanical properties and apparent porosity of KT2- kaolin mixed with 6 mass\% of magnesite.

Upon sintering at $1000{ }^{\circ} \mathrm{C}$, the sample K70T30 exhibited the best stress to rupture (20 MPa) compared to the other samples sintered at the same temperature. The latter samples exhibited higher apparent porosity, justifying the observed behavior. Moreover, for the sample containing magnesite (K94M6), the level of apparent porosity was higher due to the decarbonation during sintering that significantly contributed to increasing the remaining porosity $[17,27]$. Sintering at $1000{ }^{\circ} \mathrm{C}$ tended to promote the decrease in viscosity of the amorphous phase (Arrhenius type dependence of viscosity with temperature), and therefore, promoted the initiation of viscous flow sintering of the studied samples. Consequently, an increase in the stress to rupture and a decrease in the apparent porosity were noted for most specimens. K50T50 samples despite very a low decrease in their apparent porosity exhibited the lowest stress to rupture values.

The observation of the microstructure of K50T50 samples regarding the top surface (upper side) and bottom surface (in contact with the tape carrier) allowed observing a significant heterogeneous distribution of pores, grains and amorphous phase within these samples (Figure 10). It seemed likely that the sintering did not progress uniformly in the considered samples and could explain the lower mechanical resistance collected for K50T50. In the case of the K94M6, it a high apparent porosity (close to $50 \%$ ) was observed in agreement with the low stress to rupture. Such trend seemed consistent with the importance of the source of magnesium while using mixtures with kaolin in order to promote the formation of cordierite and enhance the properties of use. Indeed, it was necessary to perform the sintering of kaolin-magnesite mixture at a higher temperature $\left(1200{ }^{\circ} \mathrm{C}\right)$ in order to obtain equivalent properties of use obtained while using kaolin-talc mixtures. Moreover, the use of 10 to 30 mass \% of talc in kaolin-talc mixtures allowed the enhancement of the stress to rupture and apparent porosity after sintering at only $1100{ }^{\circ} \mathrm{C}$. 

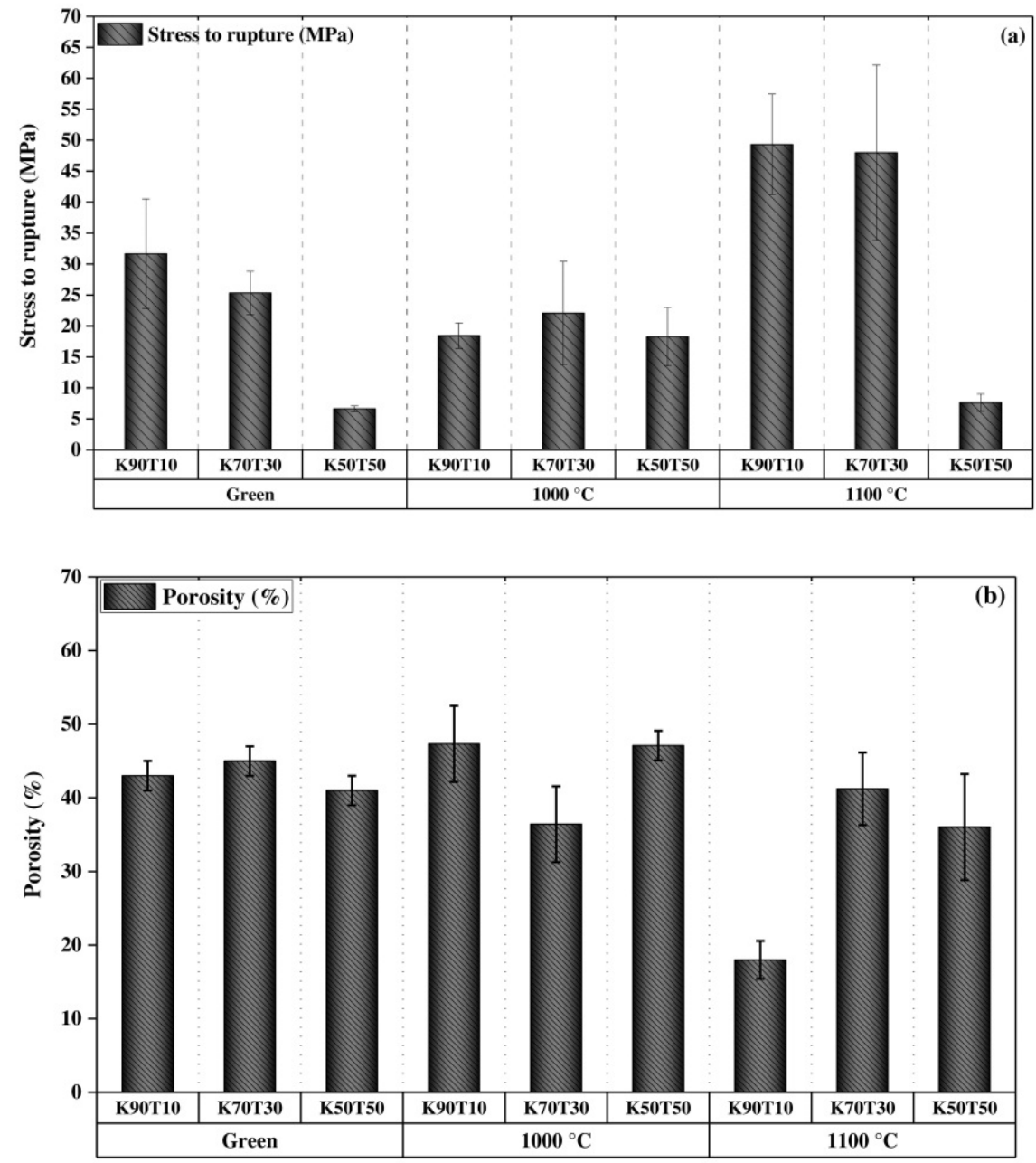

Figure 9. Comparative values of (a) the stress to rupture and (b) the apparent porosity of kaolin-talc tapes before and after sintering at 1000 and $1100{ }^{\circ} \mathrm{C}$.

\section{Upper surface}

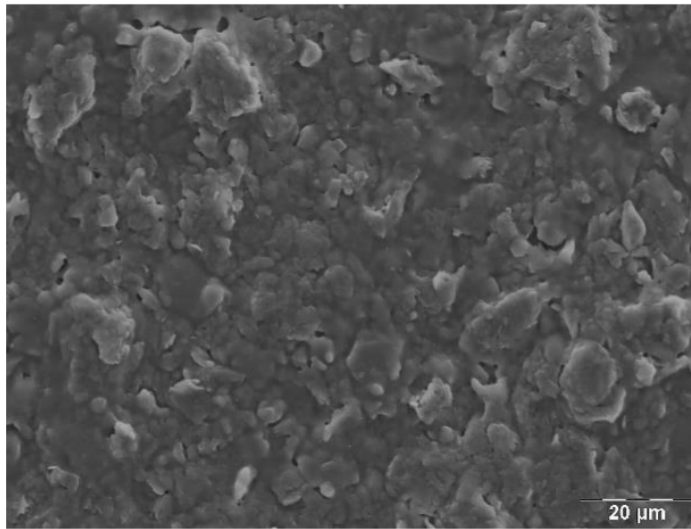

Bottom surface

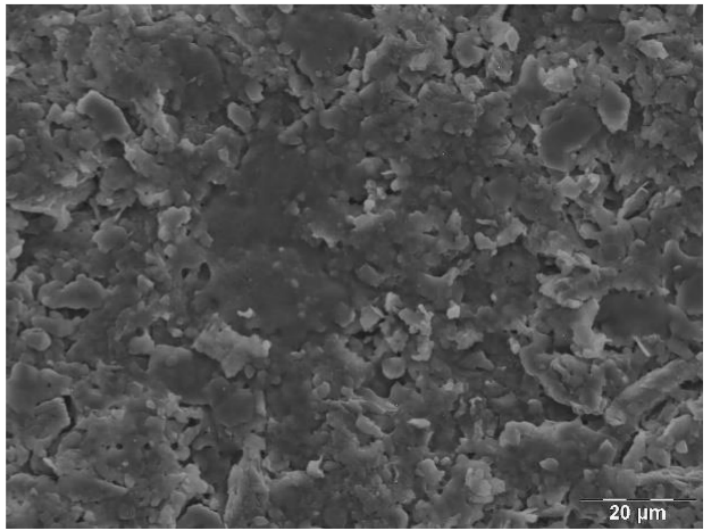

Figure 10. SEM images of $\mathrm{K} 50 \mathrm{~T} 50$ tapes sintered at $1100^{\circ} \mathrm{C}$. 


\section{Conclusions}

The present study aimed to characterize the final properties of kaolin-talc mixtures (10 to 50 mass $\%$ of talc) shaped by tape casting comparatively to those of K94M6 (kaolin-magnesite mixture with 6 mass\% of magnesite) obtained in a previous study in order to understand the effect of magnesium source regarding such cordierite-mullite ceramics.

The starting mixtures were prepared as indicated in part I of this paper, namely optimization of slurries dispersion and stability. A 0.2 mass $\%$ of dolaflux B was used as the dispersant for kaolin-talc mixtures. The sintering of samples at $1000^{\circ} \mathrm{C}$ led to porous and weak products (low stress to rupture values) compared to a sintering at $1100{ }^{\circ} \mathrm{C}$. Moreover, compared to the K94M6 sample, the apparent porosity of kaolin-talc mixtures was lowered, while their stress to rupture was increased after sintering at $1100{ }^{\circ} \mathrm{C}$. The XRD analyses of these samples indicated the presence of quartz and mullite within K94M6 tapes. In addition, mullite, quartz and cordierite (with well-defined peaks) appeared in kaolin-talc mixtures. The microstructure of K50T50 (kaolin with 50 mass $\%$ of talc) after firing at $1100{ }^{\circ} \mathrm{C}$ exhibited heterogeneous densification and distribution of pores and amorphous phase.

The results highlighted the interesting properties obtained while using a phyllosilicate such as talc as a magnesium source to produce mullite-cordierite ceramics at alower temperature with enhanced densification and mechanical properties. Nevertheless, investigations should continue regarding the influence of the heating cycle (heating rate and soaking time), the purity of kaolin and talc materials and the related thermal properties.

Author Contributions: Conceptualization, F.Z. and G.L.-N.; methodology, F.Z. and G.L.-N.; software, A.H., I.D.; validation, G.L.-N. and F.Z.; formal analysis, A.H. and G.L.-N.; investigation, A.H., I.D., N.T.-D.; resources, C.P., G.L.-N. and F.Z.; data curation, A.H., I.D., and G.L.-N.; writing-original draft preparation, A.H. and G.L.-N.; writing-review and editing, A.H. and G.L.-N.; visualization, G.L.-N.; supervision, F.Z. and G.L.-N.; project administration, F.Z., G.L.-N., N.T.-D. and C.P.; funding acquisition, F.Z. All authors have read and agreed to the published version of the manuscript.

Funding: This research received no external funding.

Conflicts of Interest: The authors declare no conflict of interest.

\section{References}

1. Hammas, A.; Lecomte-Nana, G.; Daou, I.; Zibouche, F. Sintering and final properties of kaolinite-magnesite tapes for the manufacture of cordierite-mullite ceramics. Int. J. Appl. Ceram. Technol. 2020, 17, 2265-2276. [CrossRef]

2. Corni, I.; Ryan, M.P.; Boccaccini, A.R. Electrophoretic deposition: From traditional ceramics to nanotechnology. J. Eur. Ceram. Soc. 2008, 28, 1353-1367. [CrossRef]

3. Ten, J.G.; Orts, M.J.; Saburit, A.; Silva, G. Thermal conductivity of traditional ceramics. Part I: Influence of bulk density and firing temperature. Ceram. Int. 2010, 36, 1951-1959.

4. Manfredini, T.; Hanuskova, M. Natural raw materials in "Traditional" ceramic manufacturing. J. Univ. Chem. Technol. Metall. 2012, 47, 465-470.

5. Tarvornpanich, T.; Souza, G.P.; Lee, W.E. Microstructural Evolution in Clay-Based Ceramics II: Ternary and Quaternary Mixtures of Clay, Flux, and Quartz Filler. J. Am. Ceram. Soc. 2008, 91, 2272-2280. [CrossRef]

6. Pontikes, Y.; Nikolopoulos, P.; Angelopoulos, G.N. Thermal behaviour of clay mixtures with bauxite residue for the production of heavy-clay ceramics. J. Eur. Ceram. Soc. 2007, 27, 1645-1649. [CrossRef]

7. Zbik, M.; Smart, R.S.C. Influence of dry grinding on talc and kaolinite morphology: Inhibition of nano-bubble formation and improved dispersion. Miner. Eng. 2005, 18, 969-976. [CrossRef]

8. de Brito, I.P.; de Almeida, E.P.; de Araújo Neves, G.; de Lucena Lira, H.; Menezes, R.R.; da Silva, V.J.; de Lima Santana, L.N. Development of cordierite/mullite composites using industrial wastes. Int. J. Appl. Ceram. Technol. 2020. [CrossRef]

9. Naga, S.M.; Sayed, M.; El-Omla, M.M.; Wassel, A.R.; El-Mehalawy, N. Processing of electric ceramic insulators from slate rocks and MgO. Mater. Manuf. Process. 2020, 35, 893-900. [CrossRef]

10. Sittiakkaranon, S. Thermal Shock Resistance of Mullite-Cordierite Ceramics from Kaolin, Talc and Alumina Raw Materials. Mater. Today Proc. 2019, 17, 1864-1871. [CrossRef] 
11. Lecomte-Nana, G.L.; Lebdioua, K.; Laffort, M.; Houta, N.; Tessier-Doyen, N.; Abouliatim, Y.; Peyratout, C. Effect of phyllosilicate type on the microstructure and properties of kaolin-based ceramic tapes. Ceram. Eng. Sci. Proc. 2017, 37, 47-601.

12. Tufar, W. Talc. In Ullmann's Encyclopedia of Industrial Chemistry; Wiley-VCH Verlag GmbH \& Co. KGaA: Weinheim, Germany, 2000.

13. Wattanasiriwech, S.; Wattanasiriwech, D. Roles of talc-illite on phase transformation, vitrification and physical properties of a triaxial porcelain body. J. Ceram. Process. Res. 2019, 20, 643-648. [CrossRef]

14. Lao, X.; Xu, X.; Jiang, W.; Liang, J.; Miao, L.; Wu, Q. Influences of impurities and mineralogical structure of different kaolin minerals on thermal properties of cordierite ceramics for high-temperature thermal storage. Appl. Clay Sci. 2020, 187, 105485. [CrossRef]

15. Chakraborty, A.K. Phase Transformation of Kaolinite Clay; Springer: New Delhi, India, 2014; ISBN 9788132211549.

16. Scholtzová, E.; Tunega, D. Prediction of mechanical properties of grafted kaolinite-A DFT study. Appl. Clay Sci. 2020, 193, 105692. [CrossRef]

17. Hammas, A.; Lecomte-Nana, G.; Azril, N.; Daou, I.; Peyratout, C.; Zibouche, F. Kaolinite-Magnesite Based Ceramics. Part I: Surface Charge and Rheological Properties Optimization of the Suspensions for the Processing of Cordierite-Mullite Tapes. Minerals 2019, 9, 757. [CrossRef]

18. Tunega, D.; Zaoui, A. Mechanical and Bonding Behaviors Behind the Bending Mechanism of Kaolinite Clay Layers. J. Phys. Chem. C 2020, 124, 7432-7440. [CrossRef] [PubMed]

19. Han, Y.; Liu, W.; Zhou, J.; Chen, J. Interactions between kaolinite $\mathrm{AlOH}$ surface and sodium hexametaphosphate. Appl. Surf. Sci. 2016, 387, 759-765. [CrossRef]

20. Katircioglu-Bayel, D. Impact of Operating Parameters on the Breakage Process of Talc. Mining Metall. Explor. 2020, 37, 1717-1727. [CrossRef]

21. Wang, H.; Sun, Y.; Chu, J.; Wang, X.; Zhang, M. Crystalline structure variation within phlogopite, muscovite and talc under 0-1000 kGy $\gamma$ ray irradiation: A clear dependence on intrinsic characteristic. Appl. Clay Sci. 2020, 187, 105475. [CrossRef]

22. Kirstein, A.F.; Woolley, R.M. Symmetrical bending of thin circular elastic plates on equally spaced point supports. J. Res. Natl. Bur. Stand. C 1967, 71, 1-10. [CrossRef]

23. Chen, C.Y.; Lan, G.S.; Tuan, W.H. Microstructural evolution of mullite during the sintering of kaolin powder compacts. Ceram. Int. 2000, 26, 715-720. [CrossRef]

24. Benhammou, A.; El Hafiane, Y.; Abourriche, A.; Abouliatim, Y.; Nibou, L.; Yaacoubi, A.; Tessier-Doyen, N.; Smith, A.; Tanouti, B. Influence of sintering temperature on the microstructural and mechanical properties of cordierite synthesized from andalusite and talc. Mater. Lett. 2016, 172, 198-201. [CrossRef]

25. Souto, P.M.D.; Menezes, R.R.; Kiminami, R.H.G.A. Evaluation of the Influence of $\mathrm{MgO}$ and $\mathrm{La}_{2} \mathrm{O}_{3}$ on the Fast Sintering of Mullite. Mater. Res. 2015, 18, 42-53. [CrossRef]

26. Zhu, Z.; Wei, Z.; Sun, W.; Hou, J.; He, B.; Dong, Y. Cost-effective utilization of mineral-based raw materials for preparation of porous mullite ceramic membranes via in-situ reaction method. Appl. Clay Sci. 2016, 120, 135-141. [CrossRef]

27. Hurt, S.M.; Wolf, A.S. Anomalous structure of $\mathrm{MgCO}_{3}$ liquid and the buoyancy of carbonatite melts. Earth Planet. Sci. Lett. 2020, 531, 115927. [CrossRef]

Publisher's Note: MDPI stays neutral with regard to jurisdictional claims in published maps and institutional affiliations.

(C) 2020 by the authors. Licensee MDPI, Basel, Switzerland. This article is an open access article distributed under the terms and conditions of the Creative Commons Attribution (CC BY) license (http://creativecommons.org/licenses/by/4.0/). 